\author{
ALBERT FISHLOW \\ University of California, Berkeley
}

\title{
Indexing Brazilian Style: Inflation without Tears?
}

IN EARLY 1974 the business and popular press let scarcely a week go by without some reference to the possibility of indexing bonds, savings accounts, and even contracts, to the price level. In this way, some argue, the corrosive symptoms of inflation can at least be neutralized, even if the malady itself cannot be cured.

The basic principle is not new. The search for an immutable standard traces back at least to Jevons $;^{1}$ and Irving Fisher apparently succeeded in persuading an American firm to issue an indexed bond in 1925. More recently, in the 1950s, Finland, France, and Israel, among other countries, have resorted to such practices for governmental obligations and savings accounts; and Latin American countries have experimented with deposit accounts denominated in dollars, as well as with adjustable exchange rates. $^{2}$

Renewed interest in indexing is a clear consequence of the persistence of inflation in the developed countries in recent years. Monetary and fiscal policy has been of little avail; and the apparent failure of price and wage controls, joined to the cost implications of shortfalls of energy and food

1. W. Stanley Jevons, Money and the Mechanism of Exchange (Appleton, 1898 ed.), pp. $318-26$.

2. For a brief discussion of the history of the idea of indexing (including the Fisher episode), see David Finch, "Purchasing Power Guarantees for Deferred Payments," International Monetary Fund Staff Papers, Vol. 5 (1956-57), pp. 1-22; for more recent experience, see Organisation for Economic Co-operation and Development, Committee on Financial Markets, Indexation of Fixed-Interest Securities (Paris: OECD, 1973). 
in 1973-74, seems to have spawned a sense of despair. Against this discouraging record, the apparent economic success of Brazil in recent years under a regime of "monetary correction"-a policy of widely applied indexing - is patently appealing: inflation rates have been reduced from about 90 percent in 1964 to some 15 percent in calendar year 1973; and the real growth rate has averaged more than 7 percent per capita annually from 1968 to 1973. Few countries would not opt for indexing if it could guarantee those results. There is a certain irony that the Brazilian experience should serve as the basis for the policy prescription: for years, missions from the International Monetary Fund to developing nations urged the conventional wisdom of orthodox monetary and fiscal policies to extirpate inflation; the sermon some now preach is that developed countries ought to adapt to price rises rather than to try harder to eliminate them.

Before that conclusion is too readily accepted, the recent Brazilian experience with monetary correction merits closer scrutiny. ${ }^{3}$ The logic of post hoc, propter hoc is never especially compelling, and this occasion is no exception. I have several reservations about Brazilian indexing. First, far from relying on automatic correction to general price movements, it has been characterized by significant modifications designed to accommodate to policy objectives. More generally, the reduction of inflation in Brazil owes little to indexing, but a great deal both to direct governmental intervention and to successful monetary and fiscal policy. Second, monetary correction, as applied, not only did not correct inequities generated by rapid price rises, but in fact reinforced them. Finally, the undeniably positive effects of indexing upon Brazilian growth seem to flow from two features of the indexing experience that are largely irrelevant to the United States: the effect of the crawling peg of the Brazilian foreign exchange rate on exports and the creation of significant nonbank financial intermediation.

In this paper, I will first detail the types of monetary correction permitted in Brazil and the circumstances of their introduction. The second section examines the consequences of monetary correction for the reduction of inflation, the efficiency of resource allocation, and the equality of

3. Unfortunately, the accounts of the system that have been widely disseminated are partial, or factually incorrect, or both. Even prestigious journals fail; the Economist article of April 27, 1974 (pp. 82-83), while better than most, is not exempt. I have relied here on Julian Chacel, Mario Henrique Simonsen, and Arnaldo Wald, Correção Monetário (Rio de Janeiro: APEC, 1970), for earlier aspects of the system, updating its features by reference to Conjuntura Econômica. 
income distribution in Brazil. And the third explores the applicability to the United States of the Brazilian experience.

\section{Types of Monetary Correction}

An exact exposition of Brazilian monetary correction as practiced since 1964 would be quite complicated, for it has involved probably more than a hundred laws and implementing decrees. The underlying principles, fortunately, are simpler: nominal values such as bond principals, savings accounts, mortgage payments, rentals, the exchange rate, and fixed physical assets are adjusted to corresponding real magnitudes by formulas employing recent inflation rates; and wage increases are based upon average real wages prevailing over the previous twenty-four months plus prospective increases in productivity and prices. The measure of inflation used for adjustment is a general wholesale price index in all instances except rentals, where the standard is the minimum wage. ${ }^{4}$

These two types of correction were designed to serve quite different ends. Nonwage adjustments, in general, were intended to restore relative prices as a guide to the allocation of resources. The continuous acceleration of inflation in the five years preceding the military takeover in 1964 had made reliance on relative prices precarious at best; some types of markets-for long-term securities, for example-simply did not exist. Contracts among individuals could legally be indexed, and some were. But banks were not eager to insist upon the practice: they made their profits from the spread between interest rates paid to depositors and received from borrowers, and the spread widened with greater inflation even though both real rates became negative. With borrowers obviously against it, and savers for it, no ready conjunction of interests encouraged extension of monetary correction in the private sector by itself. Governmental intervention was required and came to pass in 1964 as part of the effort that the new government made to restore the market calculus.

4. The wholesale price index used in Brazil includes only commodities, although services account for more than half of income originating. Weights in principle correspond approximately to value added in producing sectors, but closer examination reveals obvious inconsistencies. Metal products constitute 15 percent of the weight of industrial products in the index, about the same as processed foods; yet the latter were about twice as important in industrial value added in the base year.

So long as inflation is high, the choice of the index is relatively unimportant. As rates are lower, the decision becomes more significant. 
The formal system of indexing had its specific origin in mid-1964 when three- to five-year readjustable government bonds were first issued to help finance the still large federal deficit. The principal of the debt was subject to full revaluation on a quarterly basis; the indicated real interest rate was applied to this revised value. At the same time, balances owed to the government for taxes or social security contributions were put on a real basis. Subsequently, income tax brackets were regularly redefined.

In the same year mortgage loans were indexed, and a national housing bank and related private institutions were created. Resources were to be drawn at first mostly from compulsory contributions of the social security system, as well as from indexed savings accounts and securities; residential construction was to be the chief beneficiary. The aim was to expand the supply of long-term mortgage funds, which rapid inflation had so curtailed that virtually the only remaining source had been public funds allocated from social security receipts. These funds were inadequate at best and had to be rationed to restrict excess demand; furthermore, they, too, suffered erosion in real value and had to be supplemented by current governmental proceeds to satisfy the required outflow of social security payments themselves.

Indexing was also applied to time deposits of commercial banks and newly established investment banks, in an effort to make private saving considerably more attractive. Not all liabilities were treated in this way, however. Commercial acceptances, the principal nonmonetary asset both at that time and today, carried no such adjustment because of their short duration-typically, 180 days. Nominal, fixed, interest rates prevailed for this instrument, but with an incidental advantage (later altered) that for tax purposes the profit could be calculated in real terms ex post. On the asset side, short-term loans dominate, even for investment banks. Here, nominal principal repayment and correspondingly higher interest rates are the rule; indeed, one of the principal failures of monetary policy in recent years has been the inability to reduce these rates despite deceleration of inflation.

Beyond the far-reaching modifications for banks and the mortgage market, the privilege of regular revaluation was extended to two other areas in the early years of the new government. One was the rental market; another, the private productive sector. For both, some adjustments had been applied, albeit irregularly and incompletely, as early as the 1950s. The chief complaints concerning the adjustment for rentals had been that 
they neither adequately corresponded to inflation nor were made frequently enough. The annual adjustment cycle adopted in 1964, which linked rents to the minimum wage, corrected these deficiencies. Moreover, because rents had been frozen in the early 1960s-partly as a populist gesture, partly as an anti-inflationary stratagem-the initial corrections substantially exceeded those subsequently allowed by the formula.

For the productive sector, the principal problem was the exaggeration of nominal profits by the failure to account for the erosive effect inflation had on replacement allowances. The pressing concern was the right to revalue capital assets from initial historical cost. Although revaluation for some purposes was first permitted in 1951, and was made automatic in 1958 under the impetus of an excess profits tax, it was still not satisfactory to the firms. The appreciation in asset values arising from inflation was itself subject to tax, and more important, could not serve as a basis for calculating depreciation for computing taxable profits. Its only purpose was to reduce liability under the excess profits tax, which could be, and was, simply evaded. ${ }^{5}$ Even during the raging 80 percent inflation in 1963, the revaluation of total corporate capital amounted to only 27 percent; but in the twelve-month period October 1964 through September 1965, with lesser inflation but new tax laws, the revaluation of capital values was 137 percent of initial capital costs. ${ }^{6}$ The dramatic change can be traced directly to intervening legislation that facilitated (indeed, forced) revaluation. The tax on rising asset values resulting from inflation was reduced and could be paid in installments; and it was even possible to purchase nontransferable readjustable treasury bonds (in double the amount of the tax liability) in lieu of paying taxes. At the same time the penalties were mitigated the advantages were enhanced: for the first time depreciation could be calculated on the basis of the revalued capital stock. This last provision was implemented in stages to avoid too sudden a loss in tax revenues.

In the same basic legislation, revaluation of working capital was also recognized as a legitimate expense. Initially, out of pragmatic concern with receipts, relief was limited to liabilities under the excess profits tax.

5. Excess profits taxes yielded on average about 4 percent of total income tax receipts despite high and accelerating inflation in the early 1960s. The underlying data are available in the Anuário Estatístico for indicated years.

6. Conjuntura Econômica (February and November 1965), as cited in Keith S. Rosenn, "Adaptations of the Brazilian Income Tax to Inflation," Stanford Law Review, Vol. 21 (November 1968), p. 82. Other useful information on legal aspects of Brazilian indexing can be found in this paper. 
Only at the very end of 1968 was the privilege extended to regular income tax liability. Adjustment of working capital was of particular importance in Brazil because last in-first out (LIFO) inventory accounting was not legal. (This method automatically eliminates taxation of nominal profits associated with inflation-induced capital gains and largely obviates the need for legislative correction.)

A final, and quite significant, nonwage distortion was also dealt with in 1968 through the establishment of regular mini-devaluations of the Brazilian cruzeiro on foreign exchange markets. Obviously, under the inflationary conditions that had beset Brazil, fixed exchange rates were an economic impossibility. A fluctuating exchange rate for imports had been established in the mid-1950s but finally gave way in 1961, partially under external pressure, to a more conventional fixed rate that then was subject to discrete changes. The disadvantages of the fixed rate were clear: large devaluations after a period of cumulative inflation meant significant cost increases internally; exports, meanwhile, were discouraged by the high variance in real receipts; and speculation against the cruzeiro in anticipation of devaluation ultimately could necessitate depreciation, thereby vindicating the expectations (and validating the profits). The reasons for resistance to abandoning the fixed rate were equally clear: adoption of a system of mini-devaluations before inflation had stabilized could easily have fed inflationary expectations and spurred price increases for productive inputs. Not until the rate of price increase had been brought down to about 25 percent could attention profitably be turned to the allocation question. Then Brazil followed the lead of Chile and Colombia, both of which had adopted a crawling peg for their currencies. The difference in Brazil was that comprehensive and generous export subsidies were simultaneously granted, and expansion of exports was given high priority by the government.

These measures were mainly directed toward greater allocational efficiency; the exception was monetary correction for government bonds, which was undertaken to ensure noninflationary deficit financing. In wage policy, however, the clear intent was to fight inflation. Under a new and ingenious scheme to dampen wage adjustments, the target was the average real wage over the preceding twenty-four months rather than restoration of the peak real wage at the time of the last nominal increase. ${ }^{7}$ Because

7. Initially, in 1965, the wage formula was applied to federal employees and workers subject to the minimum wage; it was extended to wage disputes in the private sector in 
inflation had been accelerating, progressively eroding average real wages, this device immediately reduced the required nominal increase. Secondly, projected rather than experienced inflation (and productivity) was the criterion. The retardation of price rises that was the goal of governmental policy could be anticipated in current wage settlements. If inflation in fact slowed on schedule, smaller nominal wage gains would nonetheless translate into real income stability. With an increment to reflect productivity increases, which was added in 1966, such a wage plan could, in principle, reduce inflationary wage pressures while augmenting real earnings.

In algebraic terms the formula for nominal wages is

$$
W_{n+1}=0.5\left(\bar{W}_{n}+\bar{W}_{n-1}\right)\left(1+r_{n+1}\right)\left(1+0.5 i_{n+1}^{e}\right) p_{n},
$$

where

$$
\begin{aligned}
W_{n+1} & =\text { the nominal wage to apply in the next twelve months } \\
\bar{W}_{n} & =\text { the real wage prevailing in the past year } \\
r & =\text { the rate of anticipated productivity increase } \\
i_{n+1}^{e} & =\text { the rate of expected inflation } \\
p_{n} & =\text { the price index at the end of period } n .
\end{aligned}
$$

In practice, real wages did decline despite the use of this wage formula. Because the central components of the formula were expectations rather than realizations, wage correction was in fact not indexed at all. Nominal wage increases could be granted in any magnitude deemed convenient, simply by assuming the appropriate rate of future inflation. Following considerable shrinkage in real wages, an element of automaticity was introduced in 1968 to compensate for the systematic understatement of price rises that had characterized wage policy for the previous three years. The new formula was

$$
W_{n+1}=0.5\left[\bar{W}_{n}\left(\frac{1+0.5 i_{n}}{1+0.5 i_{n}^{e}}\right)+\bar{W}_{n-1}\right]\left(1+r_{n+1}\right)\left(1+0.5 i_{n+1}^{e}\right) p_{n},
$$

where $i_{n}$ is the actual rate of inflation realized in the most recent period of wage setting. This formula restated the base for the new wage calculation as the real wage that would have prevailed had price expectations been

1966. Individual enterprises and workers could agree on other terms, which explains why average wages might (and did) rise more rapidly than indicated by the formula. There are also small discrepancies between the formula and the minimum wage actually announced. Military wages were not bound by the formula and in fact rose more rapidly than civil service salaries. 
realized. In the absence of an accurate estimate of future inflation, it did not assure the stability of real wages during the period between wage settlements; but in fact, more realistic projections were made and real wages ended their steep descent.

Even with the move to the new formula, no correction was made for the previous shortfall; nor has any allowance been made since 1968 for errors in forecasts of the increase in productivity. Although initially the deliberate understatement of price increases dominated the real wage settlement, as these increases were more accurately assessed, the productivity term assumed greater significance, especially under the conditions of rapid growth that Brazil experienced after 1968. Under the formula real wages inevitably rose less than productivity because the previous twenty-four months rather than a single year was used for the real wage base; more important, the gain in output per worker was in fact systematically and continuously understated.

In practice, then, Brazilian wage policy has proven virtually completely discretionary. And, indeed, so has most of the rest of the system of monetary correction. Obvious pragmatism frequently led to delays in application of monetary correction, as the prospective efficiencies in allocation were weighed against the immediate loss of governmental revenues and increased cost pressures. In addition, tax privileges, other dimensions of the cost of credit, and the very correction factors themselves constantly were manipulated to achieve particular ends. Indexing was an element of intervention and as such, was substituted for other policies.

For example, monetary correction as applied to mortgage loans has undergone extensive revision. Instead of true readjustment by the price index, mortgage payments were linked to the minimum wage. Changes in real interest rates also were arbitrarily introduced to reduce loan payments; and these changes were accompanied by correspondingly smaller credits to the pension funds that provided most of the mortgage funds. In 1973 the government raised the income taxes to be withheld on profits from acceptances, while maintaining them at minimal levels for profits on federal debt, housing bonds, and savings deposits. Furthermore, it has now ruled that only formal monetary correction is subject to deduction from taxes, and that securities with initial nominal rates no longer qualify. Both of these measures significantly affect the profitability of acceptances compared to alternative assets; tax legislation has thus imposed differential "correction." 
Finally, readjustments made in recent years no longer compensate fully for changes in the price level. The real yield on 4 percent one-year government bonds in 1973 was 1.6 percent; or to put it another way, monetary correction in 1973 in fact brought about an adjustment of only 12.8 percent against a price rise of 15.5 percent. $^{8}$ The cruzeiro was not devalued during 1973 despite this rate of price increase. Past rules for continuing devaluation were not followed in the face of improvements in the current and capital accounts of the balance of payments and of the record, and undesired, level of reserve accumulation.

Considering the fact that high rates of inflation were offset at least in part, departures from full compensation are of secondary importance. At lower rates of inflation, however, the extent of discretionary authority and market intervention loom much larger. So does the choice of index itself: one issue in Brazil is whether services should be excluded when more than half of income originates in this sector. Dissatisfaction with the rates of monetary correction implied by the wholesale price index forced an extensive reformulation of the index in 1969.

The point, then, is that adoption of indexing in Brazil has not established once and for all a rule that obviates governmental influence in allocation of resources or distribution of income. To assert that it had done so would do an injustice to the ingenuity and innovativeness of Brazilian policy makers. Nor would it accurately convey the credit owed to conscious intervention in the economy for the miracle of rapid growth and diminishing inflation. This conclusion will become clearer in the following sections, which examine in more detail the contributions of indexing to the Brazilian achievement.

\section{Effects of Monetary Correction}

Proponents of indexing stress its favorable effect on the volume and allocation of financial saving, and its protection of fixed-income recipients. But indexing is also advocated as an aid in reducing inflation that can operate through several channels: the government can draw on voluntary saving rather than central bank credit to finance the deficit; expectations can be manipulated by reducing the difference between instruments bearing

8. For yields and price index changes, see Banco Central do Brasil, Relatório Anual, 1973 (March 1974), p. 77. 
real rates of return and those with nominal rates; and higher real interest rates can restrain investment, and hence reduce aggregate demand. ${ }^{9}$

Whatever the theoretical possibilities, and despite some observations to the contrary, indexing had little or no influence in reducing Brazilian inflation. ${ }^{10}$ On this point, even the staunchest Brazilian advocates of monetary correction are unanimous; here is a sample, from the current Minister of Finance:

With respect to inflation, it is known that monetary correction, because of its neutralization of inflationary distortions, is also a feedback factor to the rate of price increase. It is true that correction permitted substantial sale of Readjustable (Treasury) Bonds to the public, thus serving to dampen inflation on the side of demand. On the other hand, it is probable that the extent of feedback has been appreciably enhanced by the large-scale application of monetary correction. ${ }^{11}$

In fact, only in 1966 were sales of governmental securities large enough to permit the government to engage simultaneously in deficit financing and monetary restraint. In 1964 the issue was negligible; in 1965 sales were more than offset by the surplus on the international trade current account, and the corresponding addition to high-powered money; and by 1967 sales to the public were less than the (corrected) interest and redemption outpayments. In more recent years government financing has depended most heavily on short-term treasury bills, sold at discount without correction; these have permitted the monetary authorities to neutralize the effects on the money supply of the accumulation of some $\$ 6$ billion in international reserves from 1968 to 1973.

The principal effect of indexing in its initial years was to introduce positive real interest rates for savers, and a fortiori for borrowers. These higher

9. For a summary discussion of the presumed consequences of indexing, see OECD, Indexation.

10. See, for example, Milton Friedman: "With it, they have been able to reduce inflation gradually from about 30 per cent in 1967 to about 15 per cent now without inhibiting rapid growth, and they may be able to succeed in gradually bringing inflation down to near zero." Newsweek, Vol. 83 (January 21, 1974), p. 80; and OECD, Indexation: "This system of complete monetary correction appears to have been instrumental in enabling the Brazilian authorities to reduce drastically the country's rate of inflation without hampering its economic growth" (p. 34).

In fact a better explanation for Brazilian success is afforded by the gradual reduction in fiscal deficits, chronicled in Table 1, along with increasing imports and price and wage controls. The high rate of growth, by providing large productivity dividends, has also been a highly significant factor.

11. Mario Henrique Simonsen, Inflacão: Gradualismo vs. Tratemento de Choque (Rio de Janeiro: APEC, 1970), p. 191. The translation is mine. 
Table 1. Instruments and Objectives of Stabilization Policy, Brazil, 1963-73

\begin{tabular}{|c|c|c|c|c|c|c|c|}
\hline \multirow[b]{2}{*}{ Year } & \multirow{2}{*}{$\begin{array}{c}\text { Federal } \\
\text { govern- } \\
\text { ment } \\
\text { deficit } \\
\text { (percent } \\
\text { of gross } \\
\text { domestic } \\
\text { product) }\end{array}$} & \multirow[b]{2}{*}{$\begin{array}{c}\text { Annual } \\
\text { nominal } \\
\text { interest } \\
\text { rate } \\
\text { (percent) }\end{array}$} & \multicolumn{5}{|c|}{ Annual percentage change } \\
\hline & & & $\begin{array}{l}\text { Money } \\
\text { supply }\end{array}$ & $\begin{array}{c}\text { Bank } \\
\text { credit to } \\
\text { private } \\
\text { sector }^{\mathrm{b}}\end{array}$ & $\begin{array}{c}\text { Real } \\
\text { minimum }_{\text {wage }^{\mathrm{c}}}\end{array}$ & $\begin{array}{c}\text { Real } \\
\text { gross } \\
\text { domestic } \\
\text { product }\end{array}$ & $\begin{array}{l}\text { Implicit } \\
\text { price } \\
\text { index for } \\
\text { gross } \\
\text { domestic } \\
\text { product }\end{array}$ \\
\hline 1963 & 4.2 & 78.4 & 64.3 & 55.1 & -8.8 & 1.5 & 78.0 \\
\hline 1964 & 3.2 & 83.0 & 84.6 & 80.3 & -0.1 & 2.9 & 87.8 \\
\hline 1965 & 1.6 & 80.2 & 76.5 & 57.5 & -6.1 & 2.7 & 55.4 \\
\hline 1966 & 1.1 & 78.0 & 15.8 & 33.6 & -7.3 & 5.1 & 38.8 \\
\hline 1967 & 1.7 & 59.9 & 43.1 & 55.8 & -3.7 & 4.8 & 27.1 \\
\hline 1968 & 1.2 & 55.7 & 42.5 & 64.8 & 1.0 & 9.3 & 27.8 \\
\hline 1969 & 0.6 & 57.4 & 32.6 & 43.2 & -3.9 & 9.0 & 22.3 \\
\hline 1970 & 0.4 & 54.3 & 26.7 & 34.4 & -0.8 & 9.5 & 19.8 \\
\hline 1971 & 0.2 & 54.3 & 31.3 & 45.5 & -0.9 & 11.3 & 20.4 \\
\hline 1972 & 0.2 & 49.0 & 33.5 & 45.1 & 2.8 & 10.4 & 17.0 \\
\hline 1973 & -0.1 & 44.4 & 46.8 & 45.4 & 3.8 & 11.4 & $16.5^{\mathrm{d}}$ \\
\hline
\end{tabular}

Sources: Relevant issues of Conjuntura Econômica, and Supplement; Boletim do Banco Central do Brasil Anuário Estatístico; and Banco Central do Brasil, Relatório Anual, 1972 (1973).

a. Monthly acceptance rate to borrowers, compounded for twelve periods; 1964 and 1963 are extrapolated from the rate paid to lenders.

b. December-to-December change.

c. Deflated by cost of living index, and inclusive of salary bonuses. Wages in Guanabara were used as the base.

d. Change in wholesale price index (the corresponding change in the wholesale price index from 1971 to 1972 was 18.5 percent).

costs contributed to rising prices; and, because nonbank sources of credit responded only minimally and bank credit was curtailed, they provoked two recessions in Brazil, in mid-1965 and in the last quarter of 1966. The first was moderated by a partially accidental monetary expansion that was based on the trade flows; the second, by a significant change in economic policy that helped spark economic growth. ${ }^{12}$

Table 1 compiles some of the relevant statistical dimensions of the instruments and goals of stabilization policy. Between 1964 and 1967, the government succeeded in curbing the cash deficit and slowing the rate of increase of wages; in 1966 it applied severe monetary restraint. As a result, inflation was reduced to half its 1963 rate and growth in real per capita product, although modest, was at least positive. Yet the annual data on both indicators conceal the true state of the economy in March 1967 when

12. For a more elaborate account of post-1964 attempts to cope with inflation, see my essay, "Some Reflections on Post-1964 Brazilian Economic Policy," in Alfred Stepan (ed.), Authoritarian Brazil: Origins, Policies, and Future (Yale University Press, 1973). 
the new government took power. The economy was deep in recession and the annual inflation rate of 32 percent experienced in the first quarter was threatening to accelerate.

In the face of such circumstances, orthodox economists, and the IMF, called for renewed restraint and continued patience, while those who made Brazilian economic policy before 1967 pointed to the light at the end of the tunnel if only the faith were kept. The new government, more mindful of the mounting internal complaints in the three years since the military coup, failed to accept the external advice. Instead, they increased the deficit; expanded the supply of money and, in particular, credit to the private sector more rapidly; and, even in the absence of greater productivity gains, scaled minimum wage adjustments more closely to the cost of living index. Efforts to reduce nominal interest rates were also begun, by lowering real interest rates on governmental securities and by direct pressure from the monetary authorities on commercial banks and acceptance companies. While these efforts were only partially rewarded (the margin for intermediation remained inordinately high), the greater availability of credit, which was perhaps more important than its price, was sufficient to underwrite continuing expansion. In any event, the government was careful to allow sufficient inflation to validate the high nominal rates.

These new policies succeeded admirably and helped to set the stage for the very high levels of real income growth in recent years. They succeeded because by 1967 the Brazilian economy was not subject either to excess aggregate demand or to permissive wage settlements. In fact, considerable excess capacity existed in the industrial sector, and as Table 1 shows, real wages had been continually reduced after 1964 . Once the deficit had been brought under control by 1965, tighter reins on money demand in 1966 restrained output, but not prices, in the industrial sector. A highly concentrated market structure, and important economies of scale in the branches of industry established during the previous surge of import substitution, explains the resistance. Under the spur of two sharp recessions, price behavior altered, as the decline in inflation after 1964 testifies; but the tradeoff between price stability and real output growth was not particularly favorable, nor did it seem to be becoming more so. The new government chose to accept inflation in the pursuit of faster output growth.

This second phase of the Brazilian experience, covering the seven years 1967-73, has seen only gradual further slowing of inflation, more modest than that achieved in the 1964-67 period. The bias in favor of growth was 
clear. Monetary correction was extended to the foreign exchange rate in 1968. In addition, indexing became a more flexible instrument, but with the unvarying intent of restraining, rather than encouraging, higher real interest rates. In this respect Brazilian policy differed significantly from say, anti-inflationary strategy in Korea, where high interest rates were extended to demand deposits as a means of encouraging larger balances. In Brazil, monetary holdings were absorbed in increasing quantities less by virtue of price effects than as a consequence of the need to finance renewed growth.

Direct governmental intervention to limit industrial prices was another important part of this second phase. A new agency to review requests for price increases was established in the Finance Ministry in 1968, and took its responsibilities seriously. Requests for price increases had to be submitted to it, and the minister himself participated in the most important and delicate cases. Price increases had to be justified by proven cost increases, with allowance made for offsetting productivity gains. These controls were far sterner than those applied-not unsuccessfully-in 1965: the earlier measures had been viewed as a temporary expedient at best; moreover, compliance was voluntary, elicited by fiscal incentives and more generous availability of credit.

In short, after 1967, the emphasis shifted to more expansionary, and more pragmatic, policies. Earlier, concern had centered not only on inflation, but also-and even more-on restoring the role of the market. That is why monetary correction was tolerated from its very inception despite its possibly negative contribution to the battle against inflation. Indexing and the rapid readjustment of prices in previously controlled areas like rents, public utilities, and favored imports, were ideological commitments, and not merely technical decisions. The perceived task was to reorder the system, and orthodox policies were used partly as a punitive device to help along this reordering so that such policies themselves could work more effectively.

Although monetary correction was thus established early on, its allocative consequences were largely postponed until economic recovery got well under way. What mattered initially was not saving, but expenditure. The post-1967 Brazilian strategy rested on the excess industrial capacity persisting from an earlier cycle, which had been inspired by import substitution and had peaked in the early 1960s. Among the activities leading the recovery, construction and consumer durables were prominent, the former 
especially in 1967 and 1968, and the latter beginning in 1968. Strikingly, while both sectors are tied firmly to financial intermediation, monetary correction was of direct significance for neither. Acceptances were always quoted in nominal terms, and it was their high yield and short duration that attracted investors. Mortgages were obviously of longer term, but until the end of 1973 the obligatory social security deposits were the dominant source of mortgage financing, as Table 2 demonstrates. As far as the short term is concerned, therefore, indexing was not a significant factor in the Brazilian upturn.

Over the longer term, particularly as saving and investment requirements increased more rapidly than gross product, indexing deserves more credit. Table 2 clearly indicates an impressive and continuing increase in nonmonetary financial assets from the late 1960s on. Not all of the growth corresponded to augmented private saving, however. First, some substitution for other financial assets, including money, came about in response to interest rate differentials. Second, some saving that previously had been directly invested was channeled through intermediaries; the earlier absence of a mortgage market had resulted in high downpayments and short maturities. Third, there is quite possibly some double counting of assets held within financial institutions. Furthermore, a heavy proportion of the financial assets were simply channeled into purchases of consumer durables. Acceptances, the instrument used for this purpose, account for more than a third of the assets.

The effect of indexing on aggregate saving is therefore difficult to quantify. It is certain that the public sector has also been a major factor in supplying required resources, through the surpluses of government enterprises, controls over current outlays, and creation of obligatory contributory programs. But whatever the effect on saving may have been, intensified intermediation was a significant factor by itself. While credit might have been expensive, it could at least be predictably obtained. There can be little doubt that an organized capital market did much to dispel the uncertainty and inefficiencies of previous years.

Monetary correction thus provided a framework within which rapid growth could more easily generate the resources required to sustain itself. The vision that seemed so remote in 1965 when indexing was established for financial assets has been partly-but not entirely-fulfilled. The expected long-term capital market, in which investment banks would figure prominently, has not materialized; these banks deal principally in loans of less 


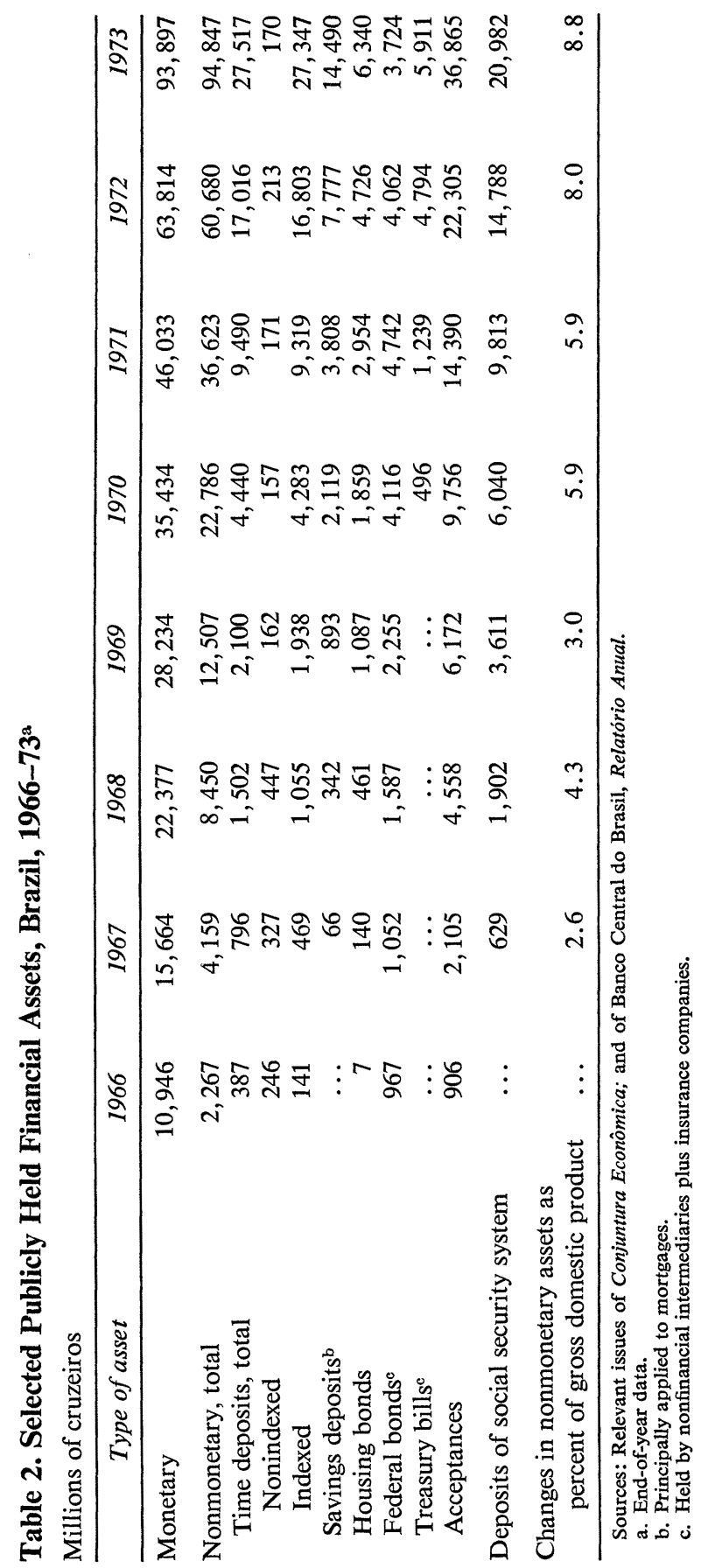


than two years for working capital. Monetary correction has not been enough. Partly to compensate for this deficiency, and to reduce interest rates, foreign loans were increasingly sought after 1970 . With interest rates in the Eurodollar market quite low at the time, the supply was especially responsive. But because the embarrassment of riches complicated shortterm monetary management, such dependence was actively discouraged in the second half of 1973. Lately, in the face of soaring petroleum prices, foreign loans have been welcomed again. Yet the problem of finance for long-term private investment remains. Efforts are currently being made to introduce debentures, convertible and fixed, as a means of encouraging the supply of longer-term capital. Fiscal incentives have been abundantly bestowed; whether they will be as successful in inducing the desired response as past measures on the short side of the market have been, remains to be seen.

A second clear success for indexing has been in the foreign trade sector, where exports have grown at an average annual rate of 27 percent since 1968. While the expansion of manufactured exports has been especially publicized, nontraditional agricultural products have figured almost as impressively, aided, to be sure, by rising international prices, but without benefit of the extensive export subsidies granted to manufactures. ${ }^{13}$ Under the impulse of the crawling peg, and with rising import capacity, the economy has increased its openness quite significantly in recent years. Because of this transformation the Brazilian economy is much better able to absorb the shock of higher petroleum prices than most other developing countries.

Indexing might have been expected to improve income distribution, as it provided more favorable opportunities to those least able to hedge against inflation. In fact, however, the results of monetary correction, as it was applied in purposive fashion against wages, seem to have been quite regressive by any standard. In the first phase of inflationary control, real minimum wages declined by some 16 percent, although average industrial real wages did rise by perhaps 7 percent between 1964 and 1967. Thereafter, while the former continued relatively constant, and the latter increased, average real wages rose considerably less than productivity gains. Average

13. Exports of industrial products (narrow definition) increased from $\$ 130$ million in 1968 to approximately $\$ 1$ billion in 1973, and thus from 1 percent of exports to 16 percent. Nontraditional agricultural exports have expanded from about $\$ 400$ million to more than $\$ 2.5$ billion in the same period. (These calculations are based upon initial estimates of 1973 exports in Conjuntura Econômica, February 1974.) 
real wages in the urban sector, as measured by the Ministry of Labor and deflated by the cost of living, increased by only 12 percent between April 1967 and April 1971, compared with productivity gains more than twice as great. In the industrial sector average annual wages deflated by industrial prices rose more rapidly-19 percent between 1967 and 1971-but compared with an increase in product per worker of at least 32 percent, the reward hardly seems generous. Only in 1972 did it seem that wages paralleled productivity advances; in 1973, they modestly exceeded them. Under these circumstances, the functional distribution of income altered in favor of capital, and studies in the size distribution indicate a parallel move in favor of higher incomes, as might be expected. This the government has finally conceded. ${ }^{14}$

There is still reluctance, however, to grant that economic policy has played a part in this process. The wage policy, in particular, is praised for its elimination of disputes and its guarantee of industrial peace. Yet, whatever the conceptual merits of the original formula as a device for curbing wage demands equitably and in a self-justifying fashion, its application was hardly undertaken in this spirit. The economic rationalization was prior excesses of labor: "The first sin of past laborism was the obsessive preoccupation with massively high salaries. These were far beyond the productivity and growth increment possible from production. The natural result of this illusion was acceleration of the inflationary process." 15 A more careful analysis of the wage-price spiral fails to support such a claim: real minimum wage costs, including all social security supplements, declined by 13 percent between 1957-60 and 1962-63 and should have provided a margin for greater price restraint, particularly since there was a concomitant increase in productivity of some 15 percent. But control of wages by the newly installed military government also served a political function. The urban working classes were a principal source of support for the emerging populist regime that had just been toppled.

Nor can the association of education with income gains exonerate the deliberate decisions of policy makers. It is tautological to presume that, because the incomes of the university-educated increased by 52 percent

14. For discussion of this and other issues concerning the state and change of income distribution in Brazil, see my recent "Brazilian Income Size Distribution-Another Look" (1973; processed).

15. Roberto Campos, the first Minister of Planning, as quoted in Octavio Ianni, Crisis in Brazil (Columbia University Press, 1970), p. 189. 
while those of illiterates remained constant during the sixties, markets were validating merited skill differentials. In fact one can show that such returns imply implausible shift factors for relative demand or, in other words, that relative incomes were not merely the reflection of marginal productivities. ${ }^{16}$ At the bottom of the income spectrum, firms took advantage of governmental fiat and the absence of employee organizations to restrict wage payments. At the upper extreme, payments for administrators and other salaried employees were probably closely linked to the higher profits being earned, and jobs were created to absorb the greater supply of educated workers.

These distributive aspects of the Brazilian miracle are no less real than the trade and capital market statistics. Nor are they less closely related to the system of monetary correction. In the first phase of post-1964 policy, "owing to the underestimate of continuing inflation, ... [the wage formula] seems to have provoked a certain decline of real wages between 1965 and 1967, which was after all the counterpart of the relative improvement that was intended to be guaranteed to renters of property, to concessionaires supplying public utility services, to the bearers of fixed-income securities, and to the rest of the beneficiaries of corrective inflation." 17 Thereafter, underestimated productivity gains were absorbed by others in analogous fashion, while monetary correction could be manipulated as needed to reduce the real rate of return on pension contributions from 5 to 3 percent, while maintaining high real returns and tax advantages for purchasers of acceptances.

\section{Lessons for the United States?}

The debate about indexing in the United States obviously will not be resolved by analysis of the Brazilian experience. The merits of indexing in the totally different U.S. context must be judged by what it promises to deliver here. It is germane, however, that the instances of its most striking success in Brazil are quite inapplicable to the American economy.

In Brazil and other Latin American countries, where rates of inflation had reached levels of 40 and 50 percent and beyond, monetary correction

16. "Brazilian Income Size Distribution-Another Look," pp. 13-16.

17. Simonsen, Inflacão, p. 184 (my translation). Corrective inflation refers to the once-for-all readjustment of rents, utility rates, and so on, as undertaken after 1964. 
was a valuable-indeed, a necessary-device to restore interest rates and exchange rates to some meaningful allocative function. Here in the United States, although double-digit inflation rates are threatening, the capital market does not seem to be seriously malfunctioning. Interest rates have adapted to price increases, and while their adaptation does not match the full extent of current inflation, that itself may be a measure of the wisdom of the market. There is no persuasive reason why current inflation should be built into future expectations on an exactly proportional basis. Nor should low real interest rates be interpreted without regard for the unsatisfactory current earnings prospects in the productive sector.

On the international scene, an automatic crawling peg does not seem to be an adequate solution to the problems posed by the passing of the old system of fixed exchange rates. Better a flexible rate entirely than an automatic adjustment tied to an arbitrary and ill-measured set of comparative price indices. Operating under flexible rates, the market can take account of capital flows and of trade performance-which is not merely a price phenomenon-in the determination of the rate. Even the Brazilians were forced to concede as much in 1973 when they at least temporarily abandoned automaticity in favor of administrative discretion. For the United States, moreover, a policy of presumed guaranteed competitiveness hardly seems the most effective route to greater international cooperation; for a country at the margins of the trading system, the opportunities are clearly greater.

Ultimately, the Brazilian experience offers two lessons. The first is that at very high rates of inflation, a country must resort to policies that restore some semblance of rational allocative guidance. For such purposes, and particularly if the market is to be relied upon, widespread indexing may be highly effective. But an equally valid conclusion is that indexing is not a neutral and mechanical instrument. Even if it were not manipulated directly, as it was in Brazil, widespread monetary correction by its very character is not a substitute for governmental intervention, but a means of it. The following examples are illustrative. Revaluation of assets is equivalent to more accelerated depreciation for tax purposes; allowance for depletion of working capital is a differential levy on capital gains on inventory; and automatic adjustment of the limits of income tax brackets is equivalent to altering marginal tax rates.

The net effect of such policies is to reduce the "automatic" stabilization inherent in increased governmental revenue from inflation in the process 
of maintaining a presumed allocative neutrality. But that neutrality is surely ambiguous in a world in which marginal tax rates, capital gains taxes, and depreciation schedules are regularly altered to achieve certain objectives. Moreover, by perfecting the propagation of exogenous inflationary shocks, indexing exacerbates the need to use other discretionary instruments. ${ }^{18}$ The resort to price controls by Brazil is a good example. At relatively low rates of inflation, there is something to be said for not compounding the burdens upon conventional policies by making them compensate for monetary correction too.

This is not to deny the potential benefits of issuing indexed securities, or of removing legal barriers to private arrangements incorporating such correction. Such assets might well be useful. Policy makers could thereby respond efficiently to varying expectations of inflation among investors, and by such discrimination, reduce nominal interest rates. A case can also be made for guaranteed partial compensation for past price increases as a way of bringing greater order to wage negotiations. But even with the best of intentions, widespread correction for inflation cannot resolve conflicting distributional claims in a totally impartial fashion. One characteristic of recent American inflation is the transfer of real income abroad. Indexing does not do away with the market and political power of special interests to avert such losses and convert them into gains. Indeed, the Brazilian experience, by its very caricature of that proposition, makes that point forcefully.

\section{Discussion}

William Poole AND others commented on the difficulty of formulating an acceptable indexing plan. Poole cited the unsuccessful experience of the Israeli government in the early 1950s in indexing the national debt.

18. The Finnish experience is revealing on this point. After devaluation in 1967, "the rise in import prices and export incomes . . . threatened to lead, through the network of index linkages, to an inflationary spiral ..." (OECD, Indexation, pp. 35-36). The system was thereupon canceled in 1968. In Brazil, as has been frequently noted, the government has been ready to modify indexing when it has conflicted with other objectives. Currently, as inflation threatens a resurgence-prices rose more in the first quarter in 1974 than in the first half of 1973-one can anticipate much more direct intervention and much less monetary correction. 
First the exchange rate and then the consumer price index was used as a basis for indexing, but neither proved widely acceptable. The government manipulated the exchange rate and controversy arose over the construction of the CPI and whether consumer prices should be subsidized to avoid higher interest payments on the debt. Poole felt that similar controversies would be inevitable in the United States and cited labor's opposition to recently proposed changes in the CPI as an indication of the volatility of this issue. Joseph Pechman added that indexing circumvented the basic issue of getting business and labor to exercise restraint so as to help moderate inflation. An indexing formula designed to slow inflation would be as unpalatable to organized labor as wage and price controls.

The redistributional aspects of indexing received considerable attention. Robert J. Gordon noted that indexing was an attractive device for spreading the inflationary burden which, he asserted, is now borne primarily by small asset holders. However, others questioned whether the gainers and losers from inflation can be identified easily. And Fishlow emphasized that any redistribution associated with indexing would have to be deliberate rather than automatic. Specifying the redistributional scheme was a terribly difficult task and one that, in the Brazilian case, led to regressivity in the name of increased allocative efficiency. Marina Whitman noted that the recent U.S. inflation had largely benefited foreigners and U.S. farmers; no particular indexing system could have entirely prevented this pattern of redistribution. In her opinion, the most significant argument for indexing was that it could remove distortions of decision making that otherwise might be caused by rapid inflation.

Arthur Okun expressed concern that indexing would unleash a spiral of inflationary pressures. He suggested that unlimited indexing would simply transmit destabilizing shocks to the price level while partial indexing involved a tradeoff between relief from past price increases and the agony of continued inflation. However, Gordon and William Nordhaus questioned whether a fast pass-through of an inflationary shock, such as an increase in oil prices, would be worse than the lagged and variable passthrough that many models predict in the absence of indexing. Okun replied that what was needed were more impediments to the transmission of inflation so that shocks did not escalate fully throughout the wageprice structure of the economy.

John Kareken queried why indexing had not developed more extensively in private markets. Poole noted that some forms of indexing-on FHA 
mortgages, for instance-were expressly prohibited. Fishlow observed that some financial institutions in California indexed mortgages in a limited form; however, offering widespread indexing as a means of attracting deposits was prohibited. Okun suggested that inflation-oriented policiessuch as the LIFO accounting system or escalator clauses in wage settlements-were remarkably uncommon because people wanted to believe in the validity of the dollar as a yardstick for transactions and accounting. 